\title{
East Bloc Shipping Policy
}

O ver the past 25 years the Soviet Union has built up not only the world's largest submarine, fishing and research fleets, but also the largest fleet of dry cargo vessels. Moreover, with $18 \mathrm{mn}$ GRT, the Soviet Union possesses the world's sixth largest merchant fleet - larger than that of the USA. In addition, a further $5 \mathrm{mn}$ GRT operate under the flags of Bulgaria, Czechoslovakia, the German Democratic Republic, Hungary and Poland. Nearly all East Bloc fleets already possess all kinds of modern vessels and all are pursuing a policy of further modernisation. For the Soviet Union alone there are at present numerous conventional freighters under construction, 29 fully containerised and 40 semi-containerised ships, 2 barge carriers and 38 ferry/passenger ships.

There is the concern felt by Western shipowners about this expansion of the Soviet merchant fleet. For that expansion bears no proportion to the Soviet Union's sea-borne foreign trade. But then this great expansion of, say, Soviet shipping is intended to serve very different purposes. The East-European countries' shipping policy has three stages; firstly, to replace chartered foreign tonnage with vessels of their own; secondly, to replace foreign carriers by offering more modern and technically superior vessels and, thirdly, to achieve the competitive advantage which technically superior ships give them to penetrate, first, the tramp shipping and subsequently the linertraffic of the West. The third stage was reached a short time ago. At present, the East European countries, having sold their sea-borne export shipments on a fob-basis, use their ships for the most part in the cross trade. For the present sea-borne imports, which are purchased on a cif-basis, are insufficient to fill the holds of the vessels; in the case of the Soviet Union, for example, imports from overseas in 1974 accounted only for about 18 p.c. of overseas exports, which totalled $118 \mathrm{mn} \mathrm{t}$. In order to avoid at least partially the inevitable voyages in ballast and at the same time to be able to participate in the lucrative general cargo trade between the highly industrialised countries, the Eastern-Bloc fleets have recently been increasing their pressure on their Western competitors in the freight market by dumping methods; they frequently undercut rates by anything between 10 p.c. to upwards of 40 p.c.

Now it could be argued that the East-Bloc fleets may well be able to ship sea freight more cheaply which, after all, can only benefit the shippers.
Such an interpretation would be wrong, however. For one thing, it is far from certain that the EastEuropean state-fleets are in fact cheaper than the privately operated Western fleets. The large Soviet subsidies are so carefully camouflaged that a cost comparison is not possible. Besides, the East European authorities are not interested in the profitability of their ships in the same way Western shipowners are; what concerns them is their usefulness as earners of foreign currency. The decisive factor therefore is that, in comparison with other branches of industry, state-run fleets are more effective in earning convertible currency. Another objective is to drive Western shipowners from the market by means of dumping. This is already to a large extent the case in the passenger trade. Should this aim be achieved, there is no reason why the cost of ocean transport should not be raised again. For even now consignors find that the Eastern Bloc fleets operate at cut rates only where the freight waiting for shipment is small. On the other hand, in the event of the cargo exceeding the available capacity, the Eastern shipping fleets have no compunction about charging the highest price they can get.

The rapid expansion of the East-Bloc fleet and the shipping policy of COMECON have also a political side to them. Whereas the Eastern Bloc and the USA are to a great extent self-sufficient, Western Europe and in particular the Federal Republic depend on their overseas trade. Should the Western European shipowners be driven out of the market either by artificially low freight rates in general or by price manipulations on the TransSiberian Railway for container freight between Western Europe and Japan or vice versa, the West European countries' supply routes would be endangered. In the event of any crisis - and also in view of the large Soviet navy - the total collapse of the Western economy would be a mere question of time.

For this reason, the governments of Western Europe will have to think of something better than the remark to the effect that the UNCTAD Code of Conduct will automatically settle all this. This Code is to allocate to the foreign trade partners in question 40 p.c. each of the foreign trade volume, while leaving the remaining 20 p.c. to the cross trade of third states. But this Code of Conduct is still far away. By then the East European shipping policy may possibly have succeeded in driving the greater part of the Western fleets from the seas.

Klaus Kwasniewski 